УДК 344.65

DOI https://doi.org/10.32837/pyuv.v0i1(30).547

\author{
O. О. Торбас \\ orcid.org/0000-0002-1465-4238 \\ кандидат юридичних наук, \\ доиент кафедри крилінального процесу \\ Національного університету «Одеська юридична академія»
}

\title{
СПОСОБИ РЕАЛІЗАЦІЇ СУДДІВСЬКОГО РОЗСУДУ В КРИМІНАЛЬНОМУ ПРОЦЕСІ УКРАЇНИ
}

Кримінальне процесуальне законодавство покладає на суддю досить важливе завдання вирішити кримінальне провадження по суті та встановити вину чи невинуватість особи. Як слушно зазначає Ю.В. Грачова, тільки судді наділені правом виносити вироки та призначати покарання, обирати його вид або розмір, а нерідко і те, і інше одночасно, з передбаченого санкцією. Також судді можуть не погодитись із правовою оцінкою обставин справи, що була запропонована, наприклад, слідчим, та надати свою. Саме оцінка, надана суддею, буде мати вирішальне кримінально-правове значення. Водночас науковець зазначає, що термін «суддівський розсуд» $є$ більш лаконічним, ніж «розсуд судді, слідчого та дізнавача», а тому саме таке формулювання є більш вживаним серед вчених-правників [1, с. 116].

Проте різноманіття кримінальних проваджень та осіб, які можуть їх вчиняти, не дає змоги законодавцю закріпити уніфіковані правила розгляду будь-якого провадження, уникнувши застосування розсуду уповноваженими на те суб'єктами. Відповідно, судді мають ефективно застосовувати як нормативні приписи, встановлені кримінальним процесуальним законодавством, так і власний розсуд у межах, встановлених КПК України.

Аналізуючи власне способи реалізації розсуду суддями в кримінальному провадженні, варто насамперед зазначити, що єдиної формули оцінки цього правового явища немає. Так, А.А. Хайдарова пропонує, наприклад, досліджувати суддівський розсуд у процесі визначення меж суддівського розсуду, в процесі судового слідства та проголошенні вироку тощо [2, с. 130]. Однак таке формулювання виглядає занадто широким, адже суддівський розсуд насамперед має оцінюватись комплексно. Якщо проаналізувати відповідні положення КПК України, то можна виділити категорії суддівського розсуду:

1) суддівський розсуд, що стосується порядку дослідження доказів (призначає проведення експертизи за клопотанням сторін кримінального провадження або потерпілого (ч. 1 ст. 332 КПК України); самостійно призначає проведення експертизи у випадках, встановлених КПК України (ч. 2 ст. 332 КПК України); визначає питання, які мають бути поставлені експерту у випадку при- значення експертизи (ч. 3 ст. 332 КПК України); визначає обсяг доказів та порядок їх дослідження з урахуванням позиції сторін (ч. 2 ст. 349 КПК України); визнає недоцільним дослідження доказів щодо тих обставин, які ніким не оспорюються (ч. 3 ст. 349 КПК України); ставить питання обвинуваченому протягом усього допиту для уточнення i доповнення його відповідей, вимагає конкретних відповідей від обвинуваченого (ч.ч. 1, 2 ст. 351 КПК України); знімає питання свідку, які не стосуються суті обвинувачення (ч. 8 ст. 352 КПК України); вимагає конкретних відповідей від свідка (ч. 11 ст. 352 КПК України); приймає рішення про повторний допит свідка (ч. 14 ст. 352 КПК України); приймає рішення про виклик експерта для допиту (ч. 1 ст. 356 КПК України); призначає одночасний допит двох чи більше вже допитаних експертів (ч. 4 ст. 356 КПК України); приймає рішення про огляд речових доказів за їх місцезнаходженням (ч. 2 ст. 357 КПК України); приймає рішення про оголошення змісту документів у судовому засідання (ч. 1 ст. 358 КПК України); виключає документ із числа доказів або призначає відповідну експертизу для цього документа (ч. 3 ст. 358 КПК України); приймає рішення про повторне відтворення звуко- чи відеозапису (ч. 2 ст. 359 КПК України); залучає спеціаліста для дослідження звуко- і відеозаписів (ч. 3 ст. 359 КПК України); користується консультаціями спеціаліста (ч. 1 ст. 360 КПК України); ставить питання спеціалісту (ч. 2 ст. $360 \mathrm{K \Pi К}$ України); приймає рішення про проведення огляду на місці (ч. 1 ст. 361 КПК України));

2) суддівський розсуд, що стосується порядку реалізації судового слідства (приймає рішення щодо застосування заходів забезпечення кримінального провадження та проведення слідчих (розшукових) дій за клопотанням учасників кримінального провадження (ст. 333 КПК України); приймає рішення про проведення допиту обвинуваченого в режимі відеоконференції (ч. 3 ст. 351 КПК України); приймає рішення про допит свідка за відсутності іншого свідка (ч. 5 ст. 352 КПК України); приймає рішення про допит свідка 3 іншого приміщення (ч. 9 ст. 352 КПК України); приймає рішення про залишення свідка в залі судового засідання після 
допиту (ч. 15 ст. 352 КПК України); відводить питання малолітньому або неповнолітньому свідку (ч. 3ст. 354КПКУкраїни); приймаєрішенняпродопит малолітнього або неповнолітнього свідка в режимівідеоконференції(ч. 4 ст. 354КПКУкраїни));

3) суддівський розсуд, що стосується забезпечення руху кримінального провадження (вирішує питання про доцільність розпочинати судовий розгляд з початку в разі зміни судді (ч. 2 ст. 319 КПК України); обмежує тривалість оголошення прокурором короткого викладу обвинувального акта, а також оголошення короткого викладу позовної заяви (ч. 4 ст. 347 КПК України); встановлює можливість розгляду цивільного позову без участі цивільного позивача (ч. 1 ст. 326 КПК України); приймає рішення про можливість проведення судового засідання без цивільного відповідача, представника юридичної особи, щодо якої здійснюється провадження (ч.ч. 2, 3 ст. 326 КПК України); приймає рішення про зупинення досудового розслідування (ст. 335 КПК України); приймає рішення про проведення судового засідання в режимі відеоконференції (ст. 336 КПК України); зупиняе проголошення промови у випадку встановлення ознак затягування судового розгляду (абз. 5 ч. 1 ст. 349 КПК України); призначає одночасний допит двох чи більше вже допитаних учасників кримінального провадження (ч. 15 ст. 352 КПК України); визначає порядок допиту неповнолітнього свідка (ч. 1 ст. 354 КПК України); визначає порядок виступу в судових дебатах (ч. 4 ст. 364 КПК України); зупиняє виступи учасників судових дебатів (ч. 6 ст. 364 КПК України); відновляе з'ясування обставин після останнього слова обвинуваченого (ч. 4 ст. 365 КПК України));

4) суддівський розсуд, що стосується забезпечення здійснення судового розгляду (вирішує питання про залучення запасного судді (ч. 1 ст. 320 КПК України); вживає необхідних заходів для забезпечення в судовому засіданні належного порядку в статусі головуючого судового засідання (ч. 2 ст. 321 КПК України); приймає рішення про привід обвинуваченого в разі його неприбуття до суду (ч. 1 ст. 323 КПК України); встановлює поважність причин неприбуття прокурора та захисника в судове засідання (ч. 1 ст. 324 КПК України); визначає достатній час, необхідний для ознайомлення захисника тапрокурора з матеріалами кримінального провадження (ч. 4 ст. 324 КПК України); приймає рішення про можливість здійснення судового розгляду в разі неявки потерпілого та щодо можливості застосувати до нього заходу кримінального процесуального примусу (ч. 1 ст. 325 КПК України); застосовує заходи кримінального процесуального примусу до свідків за умови їх неявки (ч. 1 ст. 327 КПК України); визначає кількість присутніх у залі судового засідання (ч. 1 ст. 328 КПК України); дозволяє відступати учасникам судового засідання від правил поводження в суді (ч. 1 ст. 329 КПК України); приймає рішення щодо застосування заходів до порушників порядку судового засідання (ст. 330 КПК України); приймає рішення щодо об'єднання та виділення матеріалів кримінального провадження (ст. 334 КПК України); вирішує клопотання учасників судового провадження (ч. 1 ст. 350 КПК України); перериває перебування в нарадчій кімнаті для відпочинку з настанням нічного часу (ч. 2 ст. 367 КПК України).

Таким чином, можна зробити висновок, що можливості суду застосувати розсуд під час розгляду кримінального провадження досить широкі. Водночас необхідно зазначити, що здебільшого такий розсуд стосується або порядку дослідження доказів (що, по суті, є одним із ключових завдань судового розгляду), або власне порядку здійснення судового розгляду. Законодавець послідовно реалізує запропоновану ним тезу «суддя - це арбітр», суттєво обмеживши роль суду в процесі формування обсягу доказів та їх дослідженні. Дійсно, саме суд визначає обсяг доказів, що буде досліджуватися, проте предметом оцінки можуть бути лише ті докази, які були надані учасниками кримінального провадження. Суд не може на власний розсуд розширити таку сукупність, а її звуження потребує досить грунтовної аргументації.

Крім того, нові докази в суді можуть з'явитися тільки шляхом їх подання учасниками судового провадження. Необхідно звернути увагу, що, відповідно до ст. 333 КПК України, суд не може за власною ініціативою призначити проведення слідчих (розшукових), адже з такою ініціативою мають звернутися лише сторони кримінального провадження. Єдине виключення передбачає змогу суду самостійно призначати експертизу, проте якщо: 1) суду надані кілька висновків експертів, які суперечать один одному, а допит експертів не дав змоги усунути виявлені суперечності; 2) під час судового розгляду виникли підстави, передбачені ч. 2 ст. 509 КПК України; 3) є достатні підстави вважати висновок експерта (експертів) необгрунтованим чи таким, що суперечить іншим матеріалам справи або викликає інші обгрунтовані сумніви в його правильності. Фактично, в ч. 2 ст. 332 КПК України передбачені всі можливості суду втрутитися в змагальний процес у частині отримання додаткових доказів.

Також необхідно окремо розглянути особливості застосування суддівського розсуду на стадіях перегляду судових рішень. Насамперед варто зазначити, що процедури судового розгляду в судах першої інстанції та під час перегляду судових рішень є подібними, а тому можна констатувати тотожність форм застосування суддівського розсуду на вказаних стадіях кримінального процесу. Проте все одно необхідно вказати на окремі 
особливості реалізації суддівського розсуду саме в процесі перегляду судових рішень.

Так, суддя-доповідач застосовує розсуд для вирішення питань щодо можливості призначення провадження до розгляду. У такому разі досліджуються апеляційна та касаційна скарги на предмет їх відповідності вимогам КПК України в частині змісту, суб'єкту звернення, строків подачі тощо. При цьому умови прийняття скарг до розгляду досить чітко визначені законодавцем, а тому можна стверджувати, що суддівський розсуд у цьому разі досить суттєво обмежений нормами кримінального процесуального законодавства.

Аналогічною є ситуація 3 кінцевими процесуальними рішеннями, які можуть бути прийняті на стадіях апеляційного та касаційного провадження. За таких умов суддівський розсуд найбільш яскраво проявляється в процесі скасування судових рішень судами апеляційної та касаційної інстанції у зв'язку з істотним порушенням вимог кримінального процесуального закону. Законодавець уточнює, які саме випадки порушення вимог КПК України мають визнаватися істотними (ч. 2 ст. 412 КПК України), проте в цьому переліку зазначені лише приклади такого істотного порушення. Тобто будь-яке порушення вимог КПК України, на які посилаються учасники кримінального провадження у своїх скаргах, має бути оцінене судом, та за допомогою суддівського розсуду має бути прийняте остаточне процесуальне рішення.

Кримінальне процесуальне законодавство не містить чітких правил щодо визначення «істотності» порушення норм КПК України. Тому в правовій доктрині відсутне єдине розуміння істотності порушення вимог кримінального процесуального закону. Так, Л.О. Воскобітова залежно від змісту процесуальних вимог виокремлює два види істотних порушень кримінального процесуального закону: порушення гарантованих законом прав учасників кримінального провадження й інші порушення. Останні, на їі думку, виявляються в порушенні процесуального порядку одержання доказів, порушенні меж компетенції державних органів і службових осіб, які ведуть кримінальне провадження, порушенні послідовності руху та порядку переходу справи з однієї стадії в іншу, порушенні вимог, що висуваються до процесуальних документів [3, с. 15]. О.А. Ширванов визначає істотне порушення кримінального процесуального закону як виражене в недотриманні норм (норми) кримінального процесуального права діяння, вчинене суб'єктом кримінальних процесуальних правовідносин у формі дії чи бездіяльності в будь-якій стадії кримінального судочинства, яке шляхом позбавлення або обмеження гарантованих законом прав учасників кримінального судочинства або іншим шляхом вплинуло чи могло вплинути на законність, обгрунтованість i справедливість ухваленого рішення та потягло застосування заходів відновлення правопорядку [4, с. 69]. Н.Р. Бобечко, своєю чергою, визначає істотними порушеннями порядку кримінального провадження невиконання або дія всупереч приписам кримінального процесуального законодавства України, які закріплюють гарантії прав, свобод і законних інтересів учасників кримінального провадження, встановлюють підстави, умови, послідовність і строки проведення процесуальних дій, їх фіксацію, а також недотримання положень кримінального процесуального законодавства України, що визначають підстави, режим прийняття, оформлення, проголошення та звернення до виконання процесуальних рішень, якщо такі діяння перешкодили чи могли перешкодити ухвалити законне, обгрунтоване та справедливе судове рішення [6, с. 113].

За таких умов, незважаючи на відмінність поглядів науковців, можна помітити певні спільні риси підходу до встановлення змісту істотних порушень вимог кримінального процесуального законодавства України. Вчені намагаються окремо досліджувати істотні порушення, які впливають на права та законні інтереси учасників кримінального провадження, та інші порушення (неправильна підсудність, порушення в процесі дослідження доказів тощо). Повністю з також позицією погодитися не можна, адже будь-які порушення кримінального процесуального законодавства впливають насамперед на права та законні інтереси учасників кримінального провадження. Кримінальний процес не може існувати без суб'єктів, які його реалізують, а тому всі процедури так чи інакше пов'язані з такими суб'єктами та їх правами.

Відповідно, істотними мають визнаватися такі порушення, які суттєво обмежили або порушили права та законні інтереси учасників кримінального провадження. Для того, щоб прийняти відповідне рішення, суд має:

1) встановити, які саме права мав відповідний учасник кримінального провадження. Для цього суд має дізнатися, чи дійсно особа набула відповідного процесуального статусу в конкретному кримінальному провадженні та які саме права вона у зв'язку з набуттям такого статусу отримала. У цьому разі може бути замало встановлення лише тих прав, які передбачені нормами КПК України, адже права можуть бути встановлені міжнародними договорами або іншими нормативно-правовими актами (за умови, що вони не суперечать положенням КПК України);

2) встановити, чи булі ці права порушені. Суд має дослідити докази, які були подані учасником кримінального провадження на підтвердження того, чи права такої особи дійсно були порушені. Тоді тягар доказування таких обставин поклада- 
ється на особу, яка заявляє про порушення, а суд не має права займати активну позицію в процесі встановлення відповідних обставин;

3) визначити, чи можна вважати відповідне порушення прав істотним порушенням вимог КПК України. Саме на цьому етапі суддівський розсуд проявляється найяскравіше. Судді мають враховувати одразу низку факторів (обсяг прав, що було порушено; результати судового розгляду; забезпечення законних інтересів учасників кримінального провадження тощо), а також власний досвід задля визначення такого порушення. Очевидно, що саме тому до суддів суду апеляційної та касаційної інстанції висувають додаткові вимоги під час їх призначення на посаду, адже їхній професійний досвід також має бути суттєвим фактором у процесі прийняття остаточного судового рішення.

\section{Jimepamypa}

1. Грачева Ю.В. Судейское усмотрение в реализации уголовно-правовых норм: проблемы законотворчества, теории и практики : дис. ... докт. юрид. наук : 12.00.09. Москва, 2011. 535 с.

2. Хайдаров А.А. Судейское усмотрение и его пределы в судебных стадиях уголовного процесса России : дис. ... канд. юрид. наук : 12.00.09. Москва, 2011. 252 с.

3. Воскобитова Л.А. Существенные нарушения уголовно-процессуального закона как основание к отмене приговоров : автореф. дис. ... канд. юрид. наук : 12.00.09. Москва, 1979. $17 \mathrm{c.}$

4. Ширванов А.А. Существенные нарушения уголовно-процессуального закона как основание возвращения дел для дополнительного расследования : дис. ... канд. юрид. наук : 12.00 .09 . Москва, 1999.219 с.

5. Бобечко Н.Р. Істотне порушення кримінального процесуального закону як підстава для перевірки судових рішень в апеляційному та касаційному порядку. Науковий вісник Ужгородського національного університету. Серія Право. 2015. Випуск 32. Том 3. C. $108-114$.

\section{Анотація}

Торбас O. O. Способи реалізації суддівського розсуду в кримінальному процесі України. - Стаття.

Стаття присвячена аналізу способів реалізації розсуду суддями на судових стадіях кримінального процесу України. У статті автор зазначає, що всі повноваження суду першої інстанції, в яких може бути застосовано розсуд, можна поділити на чотири категорії: 1) суддівський розсуд, що стосується порядку дослідження доказів; 2) суддівський розсуд, що стосується порядку реалізації судового слідства; 3) суддівський розсуд, що стосується забезпечення руху кримінального провадження; 4) суддівський розсуд, що стосується забезпечення здійснення судового розгляду. При цьому автор зазначає, що здебільшого суддівський розсуд стосується або порядку дослідження доказів, або порядку здійснення судового розгляду. Водночас законодавець послідовно реалізує запропоновану ним тезу «суддя - це арбітр», суттєво обмеживши роль суду в процесі формування обсягу доказів та їх дослідженні. Дійсно, саме суд визначає обсяг доказів, що буде досліджуватися, проте предметом оцінки можуть бути лише ті докази, які були надані учасниками кримінального провадження. Суд не може на власний розсуд розширити таку сукупність, а їі звуження потребує досить грунтовної аргументації.

Також автор зазначає, що у зв'язку з подібністю процедур суддівський розсуд, що застосовується в суді першої інстанції, подібний до суддівського розсуду при перегляді судових рішень в апеляційному та касаційному порядку. За таких умов суддівський розсуд найбільш яскраво проявляється в процесі скасування судових рішень судами апеляційної та касаційної інстанції у зв'язку з істотним порушенням вимог кримінального процесуального закону. Автор зазначає, що для встановлення істотності порушення вимок КПК України суд має: 1) встановити, які саме права мав відповідний учасник кримінального провадження; 2) встановити, чи булі ці права порушені; 3) визначити, чи можна вважати відповідне порушення прав істотним порушенням вимог КПК України.

Ключові слова: суддівський розсуд, суддівський розсуд у суді першої інстанції, суддівський розсуд у судах апеляційної та касаційної інстанціях.

\section{Summary}

Torbas $0 . O$. Methods of realization judicial discretion in the criminal process of Ukraine. - Article.

This article is devoted to the analysis of realization of judicial discretion at judicial stages of criminal process of Ukraine. In the article author states that all powers of the court of first instance, in which discretion can be applied, can be divided into four categories: 1) judicial discretion concerning the procedure for examining evidences; 2) judicial discretion concerning the procedure for conducting judicial investigation; 3) judicial discretion concerning the provision of criminal proceedings; 4) judicial discretion with regard to securing the trial. Author notes that in most cases judicial discretion concerns either the procedure for examining the evidence or the procedure for conducting the trial. At the same time, the consistently implements the thesis "judge is an arbitrator", which has substantially reduced role of the court in the process of forming the volume of evidence and examining it. Indeed, only court determines amount of evidence that must be examined, but only the evidence provided by the parties to the criminal proceedings can be evaluated. Court cannot, in its sole discretion, expand this amount, and narrowing it requires a substantiated argument.

Author also notes that, in view of the similarity of procedures, judicial discretion used in the trial is similar to the judicial discretion during the review of court decisions in appeal and cassation. In this case, judicial discretion is mostly conducted by the cancellation of court decisions by courts of appeal and cassation, in connection with a substantial violation of the requirements of criminal procedural law. The author notes that in order to establish such of the violation of the requirements of the CPC of Ukraine, the court should: 1) determine what rights the respective participant of criminal proceedings had;2) determine whether these rights have been violated; 3) determine whether a corresponding violation of rights can be considered a material violation of the requirements of the CPC of Ukraine.

Key words: judicial discretion, judicial discretion during the trial, judicial discretion during appeal and cassation. 